\title{
Influence of Adjunct Cultures on Volatile Free Fatty Acids in Reduced-Fat Edam Cheeses*
}

\author{
W. Tungjaroenchai, ${ }^{1}$ C. H. White, ${ }^{1}$ W. E. Holmes, ${ }^{2}$ and M. A. Drake ${ }^{3}$ \\ ${ }^{1}$ Department of Food Science and Technology and \\ ${ }^{2}$ Mississippi State Chemical Laboratory, \\ Mississippi State University, Mississippi State 39762 \\ ${ }^{3}$ Department of Food Science, \\ North Carolina State University, Raleigh 29765
}

\section{ABSTRACT}

The effects of the adjunct cultures Lactococcus lactis ssp. diacetylactis, Brevibacterium linens BL2, Lactobacillus helveticus LH212, and Lactobacillus reuteri ATCC 23272 on volatile free fatty acid production in reduced-fat Edam cheese were studied. Lipase activity evaluation using $p$-nitrophenyl fatty acid ester substrates indicated that $L$. lactis ssp. diacetylactis showed the highest activity among the 4 adjunct cultures. Full-fat and 33\% reduced-fat control cheeses (no adjunct) were made along with 5 treatments of reduced-fat cheeses, which included individual, and a mixture of the adjunct cultures. Volatile free fatty acids of cheeses were analyzed using static headspace analysis with 4-bromofluorobenzene as an internal standard. Changes in volatile free fatty acid concentrations were found in headspace gas of cheeses after 3and 6 -mo ripening. Acetic acid was the most abundant acid detected throughout ripening. Full-fat cheese had the highest relative amount of propionic acid among the cheeses. Certain adjunct cultures had a definite role in lipolysis at particular times. Reduced-fat cheese with $L$. lactis ssp. diacetylactis at 3-mo showed the highest levels of butyric, isovaleric, n-valeric, iso-caproic, and n-caproic acid. Reduced-fat cheese with $L a c$ tobacillus reuteri at 6 mo produced the highest relative concentration of iso-caproic, n-caproic, and heptanoic, and the highest relative concentration of total acids.

(Key words: adjunct culture, volatile free fatty acids)

Abbreviation key: CRD = completely randomized design, $\mathbf{O D}=$ optical density .

Received October 31, 2002.

Accepted February 3, 2003

Corresponding author: C. H. White; e-mail: chwhite@ra. msstate.edu.

*Approved for publication as Journal Article No. J-9937 of the Mississippi Agricultural and Forestry Experiment Station, Mississippi State University. Research was completed as part of the Mississippi Agricultural and Forestry Experiment Station Project No. MIS 320902501020 .

\section{INTRODUCTION}

Pure triglycerides naturally give an oily sensational mouthfeel; however, they have a major role in contributing flavor to cheese in three different ways (Fox et al., 2000). Firstly, lipids are a source of short-chain fatty acids, which are produced by lipolysis. These free fatty acids have strong and characteristic flavors and may be precursors of other compounds. Secondly, lipid oxidation especially of polyunsaturated fatty acids also can contribute to cheese flavor; however, this is limited in cheese due to low redox potential. Finally, lipids function as a solvent for aromatic compounds not only from lipids, but also from proteins and lactose. Degree of lipolysis in cheese varies widely among varieties, from $6 \mathrm{mEq}$ free fatty acids in Gouda to $45 \mathrm{mEq} / 100$ $\mathrm{g}$ fat in Danish Blue cheese (Gripon, 1987, 1993). Lipolysis in internally bacteria-ripened cheeses, such as Gouda, Cheddar, Edam, and Swiss, is generally low compared with the mold-ripened and Italian varieties.

Short-chain free fatty acids play a significant role in the flavor of cheese (Jeon, 1994). Mixtures of alkanoic acids with carbon chains from $\mathrm{C}_{2}$ to $\mathrm{C}_{8}$ or $\mathrm{C}_{4}$ to $\mathrm{C}_{10}$ appear to impart cheese-like flavors either to naturally maturing cheese or to flavor mixtures for processed cheese (Law, 1985). Short-chain fatty acids including butyric, caproic, and capric, which are formed from milkfat degradation, are considered among the necessary constituents of Cheddar cheese flavor (Urbach, 1997). Concentrations of individual VFA are affected by cheese age and cheese composition (Dimos et al., 1996, Chin and Rosenberg, 1997, Poveda et al., 1999; Innocente et al., 2000). Volatile fatty acids have qualitative and quantitative profiles that vary during ripening and can indicate some metabolic reactions taking place during ripening (Chavarri et al., 1997). In addition, the determination of VFA is a useful parameter for evaluation of the quality of a specific type of cheese characterized by lipolysis.

Increase in the rate of lipolysis with added adjunct cultures in cheese during ripening has been observed with cheese slurries (El-Soda et al., 1992; Madkor et 
al., 1999), and Cheddar cheese (Madkor et al., 2000). Adjunct lactobacilli contributed to lipolysis in cheese, and different strains of adjunct cultures have different lipolytic activities (Weimer et al., 1997; Madkor et al., 1999). The objective of this study was to determine the profile of volatile free fatty acids during ripening of reduced-fat Edam cheeses containing adjunct cultures. The profile should allow an evaluation of the significance of lipolysis, which could serve as a basis for understanding lipolytic contribution by adjunct cultures.

\section{MATERIALS AND METHODS}

\section{Bacterial Strains}

Brevibacterium linens BL2 and Lactococcus lactis ssp. diacetylactis were obtained from Bart Weimer at Utah State University. Lactobacillus helveticus LH212 and Lactobacillus reuteri ATCC 23272 were obtained from the Department of Food Science and Technology stock cultures, Mississippi State University. Stock cultures were frozen at $-70^{\circ} \mathrm{C}$ in $30 \%$ glycerol. Before use, each strain was cultivated in appropriate media for 2 consecutive transfers. Lactobacillus helveticus and $L$. reuteri were grown in MRS broth (Difco, Detroit, MI) at $37^{\circ} \mathrm{C}$ for 16 and $12 \mathrm{~h}$, respectively. Lactococcus lactis ssp. diacetylactis was grown in MRS broth at $32^{\circ} \mathrm{C}$ for $12 \mathrm{~h}$ and $B$. linens was grown in BHI broth (Difco) at $25^{\circ} \mathrm{C}$ for $16 \mathrm{~h}$ with aeration. Absorbance readings $\left(\mathrm{OD}_{550}\right.$ and $\mathrm{OD}_{420} ; \mathbf{O D}=$ optical density) and cell counts were monitored through $24 \mathrm{~h}$ of growth for each organism to generate growth curves.

\section{Lipase Activity of Adjunct Cultures}

Frozen stock cultures of L. helveticus, L. lactis ssp. diacetyllactis, and $L$. reuteri were thawed and inoculated $(0.1 \%)$ into MRS broth and B. linens was inoculated into BHI broth. Cultures were harvested in early stationary phase according to growth curves: $L$. helveticus $\left(0.509 \mathrm{OD}_{550}, 8.46 \mathrm{log} \mathrm{cfu} / \mathrm{mL}\right), B$. linens $\left(0.284 \mathrm{OD}_{420}, 7.85 \log \mathrm{cfu} / \mathrm{mL}\right)$, L. lactis ssp. diacetylactis $\left(0.959 \mathrm{OD}_{550}, 9.07 \log \mathrm{cfu} / \mathrm{mL}\right.$, and L. reuteri $\left(0.108 \mathrm{OD}_{550}, 7.41 \log \mathrm{cfu} / \mathrm{mL}\right)$. A $100-\mathrm{mL}$ broth portion of each culture was centrifuged at $5856 \times g$ at $4^{\circ} \mathrm{C}$ for 30 min (Sorvall RC 5B Plus, Wilmington, DE). Cell pellets were washed twice with $0.05 M$ sterile sodium phosphate buffer ( $\mathrm{pH}$ 7.2). Each pellet was resuspended in $1 \mathrm{~mL}$ of $3 \mathrm{mM}$ sodium phosphate buffer containing lysozyme $(55,100$ units $/ \mathrm{mL}$ ) (Sigma, St. Louis, MO), and $0.4 M$ sucrose (Dias and Weimer, 1995). The reaction mixture was incubated for $1 \mathrm{~h}$ at $37^{\circ} \mathrm{C}$, and then $2 \mathrm{~mL}$ of $0.05 \mathrm{M}$ sodium phosphate buffer was added. Cell lysis was completed by sonica- tion with a microtip at a $30 \%$ level for $20 \mathrm{~s}$ (Sonic 300 Dismembrator, ARTEK Systems corporation, Farmingdale, NY). Volume was adjusted to $10 \mathrm{~mL}$ with 0.05 $M$ sodium phosphate buffer. The lysed cell suspension was centrifuged at $5856 \times g$ at $4^{\circ} \mathrm{C}$ for $30 \mathrm{~min}$ (Sorvall RC 5B Plus). The supernatant was microfiltered (0.22$\mu \mathrm{m}$ pore size, Sigma). Lactobacillus reuteri was used to determine the optimum lysis conditions for lipase activity determination.

Two replicates of crude enzyme extract of each of the 4 adjunct cultures were analyzed using $1.0 \mathrm{mM}$ $p$-nitrophenyl acetate, butyrate, propionate, caprate, caproate, and caprylate esters (Sigma) as substrates. Substrates were dissolved in dimethylsulfoxide and stored at $-20^{\circ} \mathrm{C}$; they were thawed to room temperature immediately before use (Blake et al., 1996). A 96well quartz plate was used instead of a plastic microtiter plate to reduce interfering reactions between substrate-dimethylsulfoxide and the microtiter plate. Each reaction mixture consisted of $100 \mu \mathrm{L}$ of $1.0 \mathrm{mM}$ substrate and $100 \mu \mathrm{L}$ of enzyme extract (lysed cell extract). The substrate was preincubated at $37^{\circ} \mathrm{C}$ in the plate before the enzyme extract was added. Two wells of $100 \mu \mathrm{L}$ of $0.05 \mathrm{mM}$ sodium phosphate buffer and $100 \mu \mathrm{L}$ of each substrate were used as blanks. The absorbance was measured using a microtiter plate spectrophotometer (Spectra Max 250, Molecular Devices Corporation, Sunnyvale, CA) at $420 \mathrm{~nm}$ at $37^{\circ} \mathrm{C}$. The measured absorbance was standardized by protein content of the enzyme extract using the bicinchoninic acid method (Smith et al., 1985). A protein standard curve was made using bovine serum albumin (Sigma, St. Louis, MO). Specific activity of lipase was then expressed as change in absorbance per hour per microgram of protein of enzyme extract.

\section{Edam Cheese Making}

A completely randomized design was used for cheese making. Twenty-one vats (triplicate batches of 7 treatments) of 33\% reduced-fat Edam cheese were manufactured within $1 \mathrm{wk}$ at the Mississippi State University dairy processing plant. Full fat and reduced fat control cheeses (no adjuncts) were made along with five treatments, which included adjuncts: L. helveticus, L. reuteri, L. lactis ssp. diacetylactis, B. linens, and a combination of these cultures. Three vats of cheeses were manufactured on the same day. For reduced fat cheeses, cheese milk was standardized to $2 \%$ fat by blending whole and skim milk. The manufacturing procedure of Edam cheese was described by Tungjaroenchai et al. (2001). 


\section{Cheese Analysis}

Cross-sectional core samples were taken from randomly selected cheese balls from each treatment for microbial counts (White et al., 1992), titratable acidity of water extract (Tunjaroenchai et al., 2001), fat by Babcock method (Bradley et al., 1992), and protein by Kjeldahl method (AOAC 920.123, 1995).

\section{Volatile Free Fatty Acids}

Chemicals and materials. A VFA standard containing formic, acetic, propionic, butyric, isobutyric, valeric, isocaproic, isovaleric, hexanoic, and heptanoic acids was obtained from Supelco; 4-bromofluorobenzene, (Matheson tri-gas, Morrow, GA) was used as an internal standard. Cheese samples ( $100 \mathrm{~g}$ of cross sectional) for volatile free fatty acids at 1,3 , and 6 mo of age were vacuum packed and stored at $-70^{\circ} \mathrm{C}$. They were thawed overnight at $7^{\circ} \mathrm{C}$ before analysis.

Sample preparation. Cheeses were finely grated using a fine shred hand grater, and aliquots of samples weighing $3 \pm 0.1 \mathrm{~g}$ were placed in a $40-\mathrm{mL}$ vial with a Teflon septum. Before grating, a layer of cheese (1 $\mathrm{cm}$ ) was removed from each surface of the sample to remove any volatiles from the packaging material. Cheeses were equilibrated in the vials for $1 \mathrm{~h}$ at room temperature $\left(25^{\circ} \mathrm{C}\right)$ before analysis.

Gas chromatography and mass spectrometry. Analyses of volatile free fatty acids by static headspace were performed in a Varian Saturn 2000 GC/MS system (Varian Inc., Walnut Creek, CA). Separation was carried out on a DB-FFAP column $(30 \mathrm{~m}$ long $\times 0.25$ $\mathrm{mm}$ i.d. $\times 0.25 \mu \mathrm{m}$ film thickness, J\&W Scientific, Folsom, CA). The internal standard gas $(2 \mathrm{mg} / \mathrm{kg}$ of 4 bromofluorobenzene in $\mathrm{N}_{2}$ ) was filled in a 0.25 -mL loop, while the column and the sample preconcentration trap reached their starting temperatures of 40 and $-100^{\circ} \mathrm{C}$, respectively. The volatile analytes were deposited to glass beads in the sample preconcentration trap. The flow rate of volatiles from the vial to the sample preconcentration trap was $5 \mathrm{~mL} / \mathrm{min}$, and 14.5 $\mathrm{mL}$ of the headspace was automatically sampled. A temperature of $70^{\circ} \mathrm{C}$ of the transfer line was maintained. Helium flushed out any residual air from the trap after the sampling. The trap was rapidly heated from -100 to $230^{\circ} \mathrm{C}$ and the carrier gas back-flushed the analytes to the column that was programmed initially at $40^{\circ} \mathrm{C}$ and reached the final temperature of $128^{\circ} \mathrm{C}$ at $8^{\circ} \mathrm{C} / \mathrm{min}$. Identification of volatile free fatty acids was based on GC-MS analyses of cheese samples, as well as by matching chromatographic retention times and spectra of standard compounds. Calibration curves of standard volatile free fatty acids were conducted by running 5,10 , and $15 \mu \mathrm{L}$ of each standard.
The curves were then used for quantification (relative concentration) of volatile free fatty acids in cheese headspace; the calculation was based on weight of cheese and then expressed as relative concentration of volatile free fatty acids in cheese headspace ( $\mathrm{ppm}$ or $\mathrm{ng} / \mathrm{g}$ of cheese).

\section{Sensory Evaluation}

Nine individuals, 6 female and 3 male, 21 to $44 \mathrm{yr}$ of age were selected from university staff and students based on availability, interest, and a demonstrated liking for cheese. Panelists had prior experience with descriptive analysis. The panel received $75 \mathrm{~h}$ of training on 14 attributes for cheese flavor (Meilgaard et al., 1991). Sensory definitions for the 14 flavor attributes (Drake et al., 2001; Suriyaphan et al., 2001; Tungjaroenchai et al., 2001) used are presented in Table 1. Attribute intensities were evaluated using a 10-point intensity scale $(0=$ flavor attribute not present; $10=$ flavor intensity extremely strong). Cheeses aged 3 and 6 mo were evaluated. Cheeses were presented to the panelists monadically and evaluated during 5 sessions over $3 \mathrm{~d}$. Samples were randomly assigned each day and order of presentation was balanced among panelists. Panelists evaluated all 3 replicates for each treatment.

\section{Statistical Analysis}

Analysis of variance using the GLM procedure and least square means separations was performed on the data using SAS (SAS Institute. Inc., 1998). Significance was established at $P=0.05$, or as indicated. Lipase activity was determined and analyzed in $4 \times 6$ (culture $\times p$-nitrophenyl fatty acid substrate) factorial arrangement of treatments in a completely randomized design (CRD):

$$
\begin{aligned}
& \text { Model } \mathrm{Y}_{\mathrm{ijk}}=\mu+\alpha_{\mathrm{i}}+\beta_{\mathrm{j}}+(\alpha \beta)_{\mathrm{ij}}+\mathrm{e}_{\mathrm{ijk}} \\
\text { Activity }= & \text { Overall mean }+(\text { culture })_{\mathrm{i}}+(\text { substrate })_{\mathrm{j}}+ \\
& (\text { culture } \times \text { substrate })_{\mathrm{ij}}+(\text { error })_{\mathrm{ijk}} \\
\mathrm{i} & =1,2,3,4(\text { culture }) \\
\mathrm{j} & =1,2,3,4,5,6 \text { (substrate }) \\
\mathrm{k} & =1,2,3(\text { replicate }) .
\end{aligned}
$$

Cheese samples aged 1, 3, and 6 mo were analyzed for fat, protein, moisture, and volatile free fatty acids. The results from the $7 \times 3$ factorial arrangement (treatment $\times$ time) of treatments in a CRD were analyzed using a similar model as above, where $\mathrm{i}=$ cheese treatment factor $(I=7), j=$ time factor $(j=3)$, and $k=3$. A similar statistical model was used for a descriptive 
Table 1. Definition of sensory attributes.

\begin{tabular}{ll}
\hline Attribute & Definition \\
\hline $\begin{array}{l}\text { Young/underdeveloped flavors } \\
\text { Milky flavors } \\
\text { Cooked }\end{array}$ & \\
Whey & Aromatics associated with cooked milk \\
Buttery flavors & Aromatics associated with Cheddar cheese whey \\
Diacetyl & Aromatics associated with diacetyl \\
Fresh milkfat/lactone & Aromatics associated with milk fat \\
Aged/Developed flavors & Aromatics associated with different fruits \\
Fruity & Aromatics associated with sulfurous compounds \\
Sulfur & Aromatics associated with short chain fatty acids \\
Free fatty acid/rancid & Aromatics associated with boiled meat or vegetable soup stock \\
Brothy & The nut-like aromatic associated with different nuts \\
Nutty & \\
Basic tastes & Fundamental taste sensation elicited by salts \\
Salty & Fundamental taste sensation elicited by sugars \\
Sweet & Fundamental taste sensation elicited by caffeine, quinine \\
Bitter & Fundamental taste sensation elicited by acids \\
Sour & Chemical feeling factor elicited by certain peptides and nucleotides \\
Umami/savory &
\end{tabular}

${ }^{1}$ Definitions are from Drake et al. (2001).
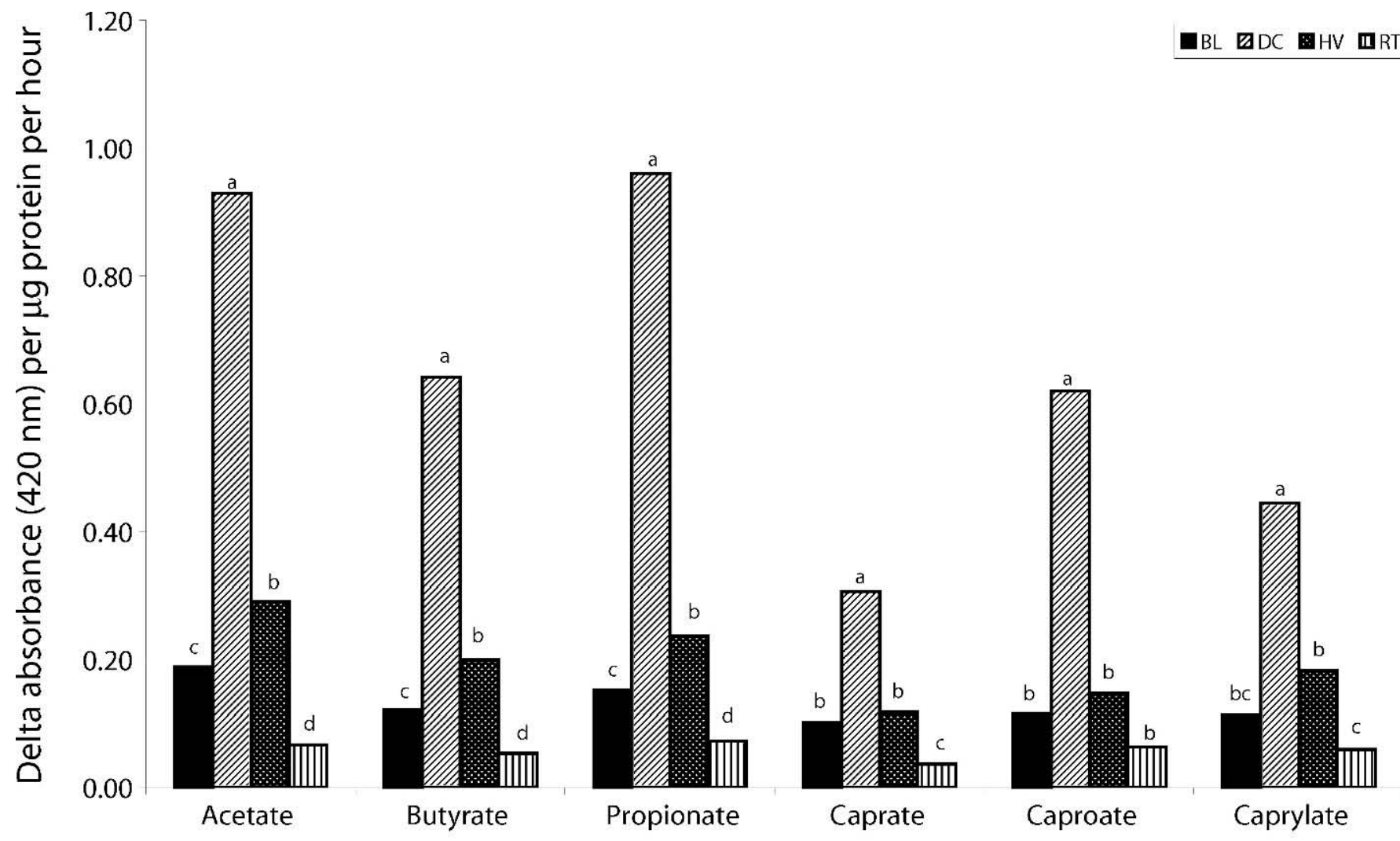

\section{p-nitrophenyl-fatty-acid ester substrates $(1.0 \mathrm{mM})$}

Figure 1. Lipase activity of Brevibacterium linens (BL), Lactococcus lactis ssp. diacetylactis (DC), Lactobacillus helveticus (HV), Lactobacillus reuteri (RT) using $p$-nitrophenyl-fatty acid ester substrates $(1.0 \mathrm{mM})$. Bars with the same letters are not significantly different $(P>0.05)$ in lipase activity for each substrate. 


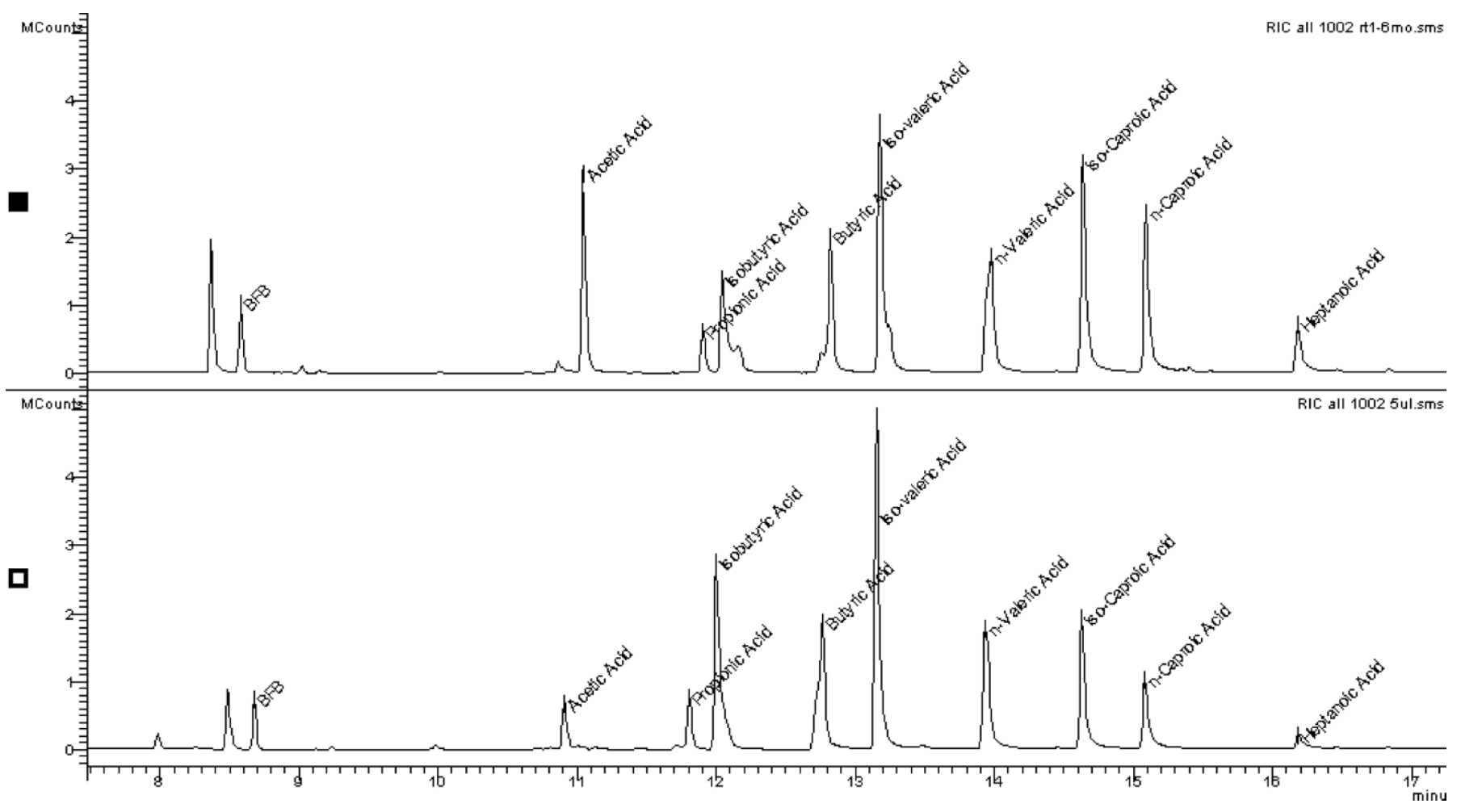

Figure 2. Gas chromatograms of volatile free fatty acids standard (bottom) and corresponding acids in a reduced-fat Edam cheese (top).

sensory evaluation of cheeses at 3 and 6 mo. A $7 \times 2$ (treatment $\times$ time) factorial arrangement in a CRD was performed on the data of descriptive sensory panel.

\section{RESULTS AND DISCUSSION}

\section{Lipase Activity}

Lactococcus lactis ssp. diacetylactis showed the highest lipase activity $(P<0.05)$ for all substrates (Figure 1). Hydrolysis of $p$-nitrophenylacetate, propionate, and butyrate substrates by Lactobacillus helveticus was much higher $(P<0.05)$ than that of $B$. linens and $L$. reuteri. The pattern of hydrolytic activity of cultures varied with the longer carbon chain of fatty acids. Lactobacillus helveticus, B. linens, and L. reuteri had similar activity towards $p$-nitrophenylcaproate $(P$ $>0.05)$. However, L. helveticus and B. linens had a higher activity towards $p$-nitrophenylcaprylate and caprate than that of $L$. reuteri $(P<0.05)$. Lactobacillus reuteri had the lowest hydrolytic activity towards $p$ nitrophenylacetate, propionate, and caprate $(P<0.05)$. Lipase activity has been measured with different cultures, substrates, and conditions (Lee and Lee, 1994, Gobbetti et al., 1996, and El-Soda et al., 1999). In this study, lipase activity of pure cultures was variable among strains and substrates. Differentiation of lipase activity among the 4 cultures was clearly obtained by using the short-chain fatty acid derivatives. Gobbetti et al. (1996) reported lipase activity decreased with increasing chain length of fatty acids. In contrast, ElSoda et al. (1995) revealed an increase in hydrolysis with an increase in the number of carbon atoms in the substrates when Lactobacillus spp. was used with nitrophenyl esters. El-Soda et al. (1986) found that activity of intracellular lipases of $L$. helveticus activity on $o$-nitrophenyl and $p$-nitrophenyl derivatives of fatty acids was specific for short-chain fatty acids. Lactobacilli had higher lipase activity than lactococci (Bardi et al., 1992). Weimer et al. (1997) reported a higher lipase activity for Lactococcus lactis ssp. lactis than that of $L$. helveticus and B. linens when $p$-nitrophenyl butyrate and caprylate were used as substrates. In addition, Gobbetti et al. (1996) found higher lipase activity in thermophilic lactobacilli than mesophilic species. Results of lipase activity tests are related not only to strains and substrates used, but also the methodology of enzyme extraction and substrates solvation are crucial to the results and their interpretation.

\section{Characterististics of Cheese During Aging}

Mean fat and protein content of reduced fat cheese were $20.9 \pm 0.7 \%$ and $51.3 \pm 1.4 \%$, respectively. The 


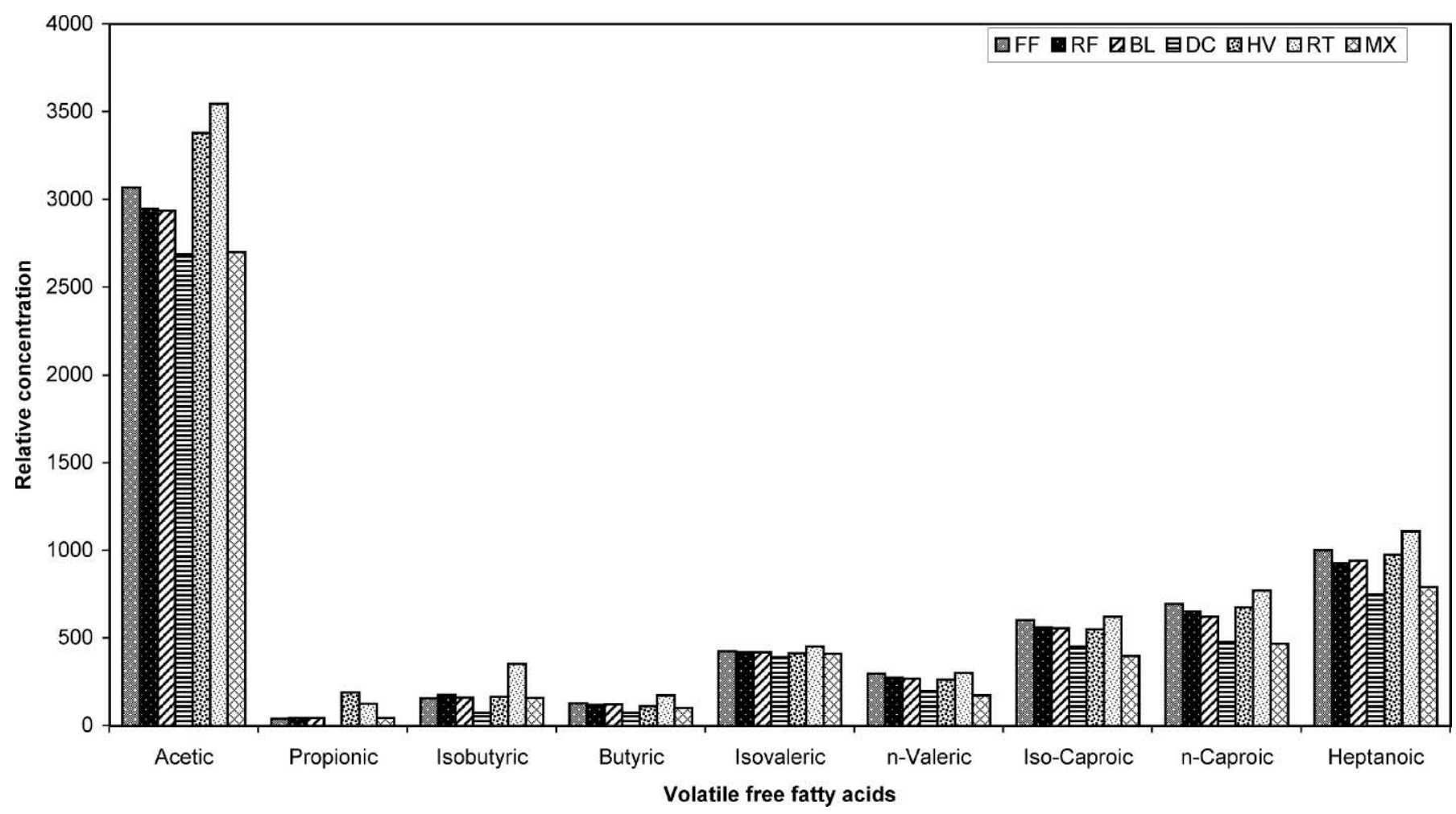

Figure 3. Volatile free fatty acids profile of 1-mo Edam cheeses: full-fat control cheese (FF), reduced-fat control cheese (RF), reducedfat cheese with Brevibacterium linens (BL), reduced-fat cheese with Lactococcus lactis ssp. diacetylactis (DC), reduced-fat cheese with Lactobacillus helveticus (HV), reduced-fat cheese with Lactobacillus reuteri (RT), reduced-fat cheese with mixed adjunct cultures (MX). Relative concentration ( $\mathrm{ng} / \mathrm{g}$ cheese) expressed based on cheese weight and internal standard recovery.

fat and protein of the full-fat control cheese were 30.1 $\pm 0.8 \%$ and $41.7 \pm 1.7 \%$, respectively. Moisture values of reduced-fat cheeses $(43.0 \pm 0.4 \%)$ were higher $(P<$ $0.05)$ than in full fat cheese $(39.1 \pm 0.6 \%)$. Lactic acid bacteria counts were higher by less than $1 \log$ for 1 mo-old reduced fat cheese $(7.23 \mathrm{log} \mathrm{cfu} / \mathrm{mL})$ than for full-fat control cheese $(6.9 \log \mathrm{cfu} / \mathrm{mL})(P<0.05)$. Counts increased in the second month $(P<0.05)$, then decreased with further aging. Titratable acidity of water extract in cheese increased with ripening $(P<0.05)$. The 1-mo full fat and reduced-fat cheeses had mean titratable acidity values of $0.83 \pm 0.13 \%$ lactic acid

Table 2. Changes in relative concentrations of propionic, acetic, and butyric acids in headspace of Edam cheese.

\begin{tabular}{|c|c|c|c|c|c|c|c|c|c|}
\hline \multirow{2}{*}{$\begin{array}{l}\text { Cheese } \\
\text { treatments }^{1}\end{array}$} & \multicolumn{3}{|c|}{ Propionic acid } & \multicolumn{3}{|c|}{ Acetic acid } & \multicolumn{3}{|c|}{ Butyric acid } \\
\hline & $1 \mathrm{mo}$ & $3 \mathrm{mo}$ & $6 \mathrm{mo}$ & $1 \mathrm{mo}$ & $3 \mathrm{mo}$ & $6 \mathrm{mo}$ & $1 \mathrm{mo}$ & $3 \mathrm{mo}$ & $6 \mathrm{mo}$ \\
\hline $\mathrm{FF}$ & $0.04^{\mathrm{bBC}}$ & $0.11^{\mathrm{bA}}$ & $0.86^{\mathrm{aA}}$ & $3.07^{\mathrm{a}}$ & $1.02^{\mathrm{bE}}$ & $0.98^{\mathrm{bE}}$ & $0.13^{\mathrm{b}}$ & $0.16^{\mathrm{bB}}$ & $1.15^{\mathrm{aA}}$ \\
\hline $\mathrm{RF}$ & $0.04^{\mathrm{bBC}}$ & $0.03^{\mathrm{bB}}$ & $0.57^{\mathrm{aB}}$ & $2.95^{\mathrm{a}}$ & $0.76^{\mathrm{cF}}$ & $1.39^{\mathrm{bED}}$ & $0.12^{\mathrm{b}}$ & $0.07^{\mathrm{bE}}$ & $0.78^{\mathrm{aB}}$ \\
\hline BL & $0.04^{\mathrm{bBC}}$ & ND & $0.42^{\mathrm{aC}}$ & $2.94^{\mathrm{a}}$ & $0.63^{\mathrm{cF}}$ & $2.04^{\mathrm{bCD}}$ & $0.12^{\mathrm{b}}$ & $0.03^{\mathrm{bF}}$ & $0.64^{\mathrm{aB}}$ \\
\hline $\mathrm{DC}$ & $\mathrm{ND}^{2}$ & $0.04^{\mathrm{bB}}$ & $0.21^{\mathrm{aD}}$ & 2.69 & $1.67^{\mathrm{D}}$ & $2.33^{\mathrm{BC}}$ & $0.07^{\mathrm{c}}$ & $0.19^{\mathrm{bA}}$ & $0.37^{\mathrm{aC}}$ \\
\hline HV & $0.19^{\mathrm{aA}}$ & $0.03^{\mathrm{bB}}$ & $0.08^{\mathrm{bD}}$ & 3.38 & $1.95^{\mathrm{C}}$ & $2.52^{\mathrm{BC}}$ & 0.11 & $0.14^{\mathrm{BC}}$ & $0.21^{\mathrm{C}}$ \\
\hline $\mathrm{RT}$ & $0.12^{\mathrm{bAB}}$ & ND & $0.52^{\mathrm{aBC}}$ & $3.54^{\mathrm{ab}}$ & $2.41^{\mathrm{bB}}$ & $4.84^{\mathrm{aA}}$ & $0.17^{\mathrm{b}}$ & $0.12^{\mathrm{bCD}}$ & $0.74^{\mathrm{aB}}$ \\
\hline MX & $0.04^{\mathrm{bBC}}$ & ND & $0.21^{\mathrm{aD}}$ & 2.70 & $2.82^{\mathrm{A}}$ & $3.08^{\mathrm{B}}$ & $0.10^{\mathrm{b}}$ & $0.11^{\mathrm{bD}}$ & $0.35^{\mathrm{aC}}$ \\
\hline
\end{tabular}

a,b,c Means without a common letter within a row differ $(P<0.01)$.

A,B,C Means without a common letter within a column differ $(P<0.01)$, and $*(P<0.05)$.

${ }^{1}$ Full-fat control cheese (FF), reduced-fat control cheese (RF), reduced-fat cheese with Brevibacterium linens (BL), reduced-fat cheese with Lactococcus lactis ssp. diacetylactis (DC), reduced-fat cheese with Lactobacillus helveticus (HV), reduced-fat cheese with Lactobacillus reuteri (RT), reduced-fat cheese with mixed adjunct cultures (MX).

${ }^{2} \mathrm{ND}=$ Not detected. 
Table 3. Changes in relative concentrations of iso-butyric, iso-valeric, and $n$-valeric acids in headspace of Edam cheese.

\begin{tabular}{|c|c|c|c|c|c|c|c|c|c|}
\hline \multirow{2}{*}{$\begin{array}{l}\text { Cheese } \\
\text { treatments }^{1}\end{array}$} & \multicolumn{3}{|c|}{ iso-Butyric acid } & \multicolumn{3}{|c|}{ iso-Valeric acid } & \multicolumn{3}{|c|}{$n$-Valeric acid } \\
\hline & $1 \mathrm{mo}$ & $3 \mathrm{mo}$ & $6 \mathrm{mo}$ & $1 \mathrm{mo}$ & $3 \mathrm{mo}$ & $6 \mathrm{mo}$ & $1 \mathrm{mo}$ & $3 \mathrm{mo}$ & $6 \mathrm{mo}$ \\
\hline $\mathrm{FF}$ & $0.16^{\mathrm{b}}$ & $0.23^{\mathrm{bA}}$ & $1.02^{\mathrm{aA}}$ & $0.43^{\mathrm{b}}$ & $0.42^{\mathrm{bBC}}$ & $1.73^{\mathrm{aA}}$ & $0.30^{\mathrm{b}}$ & $0.19^{\mathrm{bC}}$ & $1.62^{\mathrm{aA}}$ \\
\hline $\mathrm{RF}$ & $0.18^{\mathrm{b}}$ & $0.13^{\mathrm{bBC}}$ & $0.62^{\mathrm{aBC}}$ & $0.42^{\mathrm{b}}$ & $0.39^{\mathrm{bD}}$ & $1.45^{\mathrm{aAB}}$ & $0.27^{\mathrm{b}}$ & $0.09^{\mathrm{cD}}$ & $127^{\mathrm{aAB}}$ \\
\hline $\mathrm{BL}$ & $0.16^{\mathrm{ab}}$ & $0.06^{\mathrm{bD}}$ & $0.33^{\mathrm{aDC}}$ & $0.42^{\mathrm{b}}$ & $0.36^{\mathrm{bE}}$ & $1.28^{\mathrm{aB}}$ & $0.27^{\mathrm{b}}$ & $0.03^{\mathrm{cD}}$ & $1.23^{\mathrm{aB}}$ \\
\hline $\mathrm{DC}$ & $0.07^{\mathrm{b}}$ & $0.16^{\mathrm{aB}}$ & $0.12^{\mathrm{abD}}$ & $0.39^{b}$ & $0.45^{\mathrm{bA}}$ & $0.92^{\mathrm{aC}}$ & $0.20^{\mathrm{c}}$ & $0.45^{\mathrm{bA}}$ & $0.88^{\mathrm{aDC}}$ \\
\hline $\mathrm{HV}$ & 0.17 & $0.12^{\mathrm{C}}$ & $0.08^{\mathrm{D}}$ & 0.41 & $0.43^{\mathrm{B}}$ & $0.48^{\mathrm{D}}$ & 0.26 & $0.35^{\mathrm{B}}$ & $0.56^{\mathrm{D}}$ \\
\hline $\mathrm{RT}$ & $0.35^{\mathrm{b}}$ & $0.09^{\mathrm{bCD}}$ & $0.79^{\mathrm{aAB}}$ & $0.45^{\mathrm{b}}$ & $0.42^{\mathrm{bBC}}$ & $1.45^{\mathrm{aAB}}$ & $0.30^{\mathrm{b}}$ & $0.33^{\mathrm{bB}}$ & $1.11^{\mathrm{aBC}}$ \\
\hline MX & $0.16^{\mathrm{a}}$ & $0.07^{\mathrm{bD}}$ & $0.13^{\mathrm{abD}}$ & $0.41^{b}$ & $0.41^{\mathrm{bC}}$ & $0.91^{\mathrm{aC}}$ & $0.17^{\mathrm{c}}$ & $0.34^{\mathrm{bB}}$ & $0.79^{\mathrm{aDC}}$ \\
\hline
\end{tabular}

a,b,c Means without a common letter within a row differ $(P<0.01)$.

A,B,C Means without a common letter within a column differ $(P<0.01)$.

${ }^{1}$ Full-fat control cheese (FF), reduced-fat control cheese (RF), reduced-fat cheese with Brevibacterium linens (BL), reduced-fat cheese with Lactococcus lactis ssp. diacetylactis (DC), reduced-fat cheese with Lactobacillus helveticus (HV), reduced-fat cheese with Lactobacillus reuteri (RT), reduced-fat cheese with mixed adjunct cultures (MX).

with an increase to $1.4 \pm 0.1 \%$ after 6 mo of ripening at $7^{\circ} \mathrm{C}$.

\section{Volatile Free Fatty Acids}

Identification of volatile free fatty acids was based on GC-MS analyses of cheese samples, as well as by matching chromatographic retention times and spectra of standard compounds (Figure 2).

There was no effect of adjunct cultures on levels of each volatile free fatty acid in 1-mo cheeses (Figure 3 ) $(P>0.05)$, except for propionic acid $(P<0.05)$ (Table 2 ). Small amounts of volatile free fatty acids were produced in the young cheeses. In most cases the amounts of free fatty acids increased with ripening $(P<0.01)$ (Table 2, 3, 4). Acetic acid was the most abundant acid detected in cheeses through ripening. Acetate can be produced by starter bacteria or adjunct lactobacilli from amino acids, lactose, or citric acid in cheese
(Thomas, 1987; Nakae and Elliot, 1965; Lawrence et al., 1993). Acetate is usually present in high concentrations in Cheddar cheese and is considered to contribute to its flavor (Aston and Dulley, 1982). Lactate can also be oxidized by nonstarter lactic acid bacteria in cheese to acetate and $\mathrm{CO}_{2}$ (Fox et al., 1995). Acetic acid can provide an indication of degree of heterofermentative metabolism during ripening (Lawrence et al., 1993). The relative concentrations of acetic acid in cheeses declined $(P<0.01)$ during ripening (Table 2$)$. This was opposite to the concentrations observed for cheese with $L$. reuteri that showed an increase in this acid $(P<$ 0.01 ) between 1,3 , and 6 mo. A significant increase in acetic acid during ripening of full fat and one-third reduced-fat cheese was reported by Johnson and Chen (1995). This study showed that cheeses with $L$. reuteri produced the highest amount of acetic acid during 6mo ripening, while full-fat and reduced-fat control

Table 4. Changes in relative concentrations of iso-caproic, $n$-caproic, and heptanoic acids in headspace of Edam cheese.

\begin{tabular}{|c|c|c|c|c|c|c|c|c|c|}
\hline \multirow{2}{*}{$\begin{array}{l}\text { Cheese } \\
\text { treatments }^{1}\end{array}$} & \multicolumn{3}{|c|}{ iso-Caproic acid } & \multicolumn{3}{|c|}{$n$-Caproic acid } & \multicolumn{3}{|c|}{ Heptanoic acid } \\
\hline & $1 \mathrm{mo}$ & $3 \mathrm{mo}$ & $6 \mathrm{mo}$ & $1 \mathrm{mo}$ & $3 \mathrm{mo}$ & $6 \mathrm{mo}$ & $1 \mathrm{mo}$ & $3 \mathrm{mo}$ & $6 \mathrm{mo}$ \\
\hline $\mathrm{FF}$ & $0.60^{\mathrm{b}}$ & $0.29^{\mathrm{cC}}$ & $1.76^{\mathrm{aB}}$ & $0.69^{b}$ & $0.30^{\mathrm{cC}}$ & $1.62^{\mathrm{aB}}$ & $1.00^{\mathrm{b}}$ & $0.26^{\mathrm{cB}}$ & $1.80^{\mathrm{aB}}$ \\
\hline $\mathrm{RF}$ & $0.56^{\mathrm{b}}$ & $0.18^{\mathrm{cDC}}$ & $1.51^{\mathrm{aBC}}$ & $0.65^{\mathrm{b}}$ & $0.10^{\mathrm{cD}}$ & $1.52^{\mathrm{aBC}}$ & $0.93^{b}$ & $0.24^{\mathrm{cB}}$ & $1.60^{\mathrm{aBC}}$ \\
\hline $\mathrm{BL}$ & $0.56^{\mathrm{b}}$ & $0.07^{\mathrm{cD}}$ & $1.60^{\mathrm{aB}}$ & $0.62^{\mathrm{b}}$ & $0.03^{\mathrm{cD}}$ & $1.69^{\mathrm{aB}}$ & $0.94^{\mathrm{b}}$ & $0.18^{\mathrm{cB}}$ & $1.78^{\mathrm{aB}}$ \\
\hline $\mathrm{DC}$ & $0.45^{\mathrm{c}}$ & $0.83^{\mathrm{bA}}$ & $1.24^{\mathrm{aC}}$ & $0.52^{\mathrm{c}}$ & $0.93^{\mathrm{bA}}$ & $1.30^{\mathrm{aDC}}$ & 0.75 & $1.33^{\mathrm{aA}}$ & $1.54^{\mathrm{aBC}}$ \\
\hline HV & 0.55 & $0.65^{\mathrm{B}}$ & $0.92^{\mathrm{D}}$ & 0.68 & $0.76^{\mathrm{B}}$ & $1.03^{\mathrm{D}}$ & 0.98 & $1.03^{\mathrm{A}}$ & $1.26^{\mathrm{C}}$ \\
\hline $\mathrm{RT}$ & $0.62^{b}$ & $0.64^{\mathrm{bB}}$ & $2.17^{\mathrm{aA}}$ & $0.77^{\mathrm{b}}$ & $0.70^{\mathrm{bB}}$ & $2.22^{\mathrm{aA}}$ & $1.11^{\mathrm{b}}$ & $1.03^{\mathrm{bA}}$ & $2.98^{\mathrm{aA}}$ \\
\hline MX & $0.40^{\mathrm{c}}$ & $0.60^{\mathrm{bB}}$ & $1.25^{\mathrm{aC}}$ & $0.47^{\mathrm{c}}$ & $0.74^{\mathrm{bB}}$ & $1.40^{\mathrm{aBC}}$ & $0.79^{\mathrm{c}}$ & $1.06^{\mathrm{bA}}$ & $1.76^{\mathrm{aB}}$ \\
\hline
\end{tabular}

a,b,c Means without a common letter within a row differ $(P<0.01)$

$\mathrm{A}, \mathrm{B}, \mathrm{C}$ Means without a common letter within a column differ $(P<0.01)$.

${ }^{1}$ Full-fat control cheese (FF), reduced-fat control cheese (RF), reduced-fat cheese with Brevibacterium linens (BL), reduced-fat cheese with Lactococcus lactis ssp. diacetylactis (DC), reduced-fat cheese with Lactobacillus helveticus (HV), reduced-fat cheese with Lactobacillus reuteri (RT), reduced-fat cheese with mixed adjunct cultures (MX). 


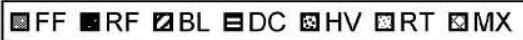

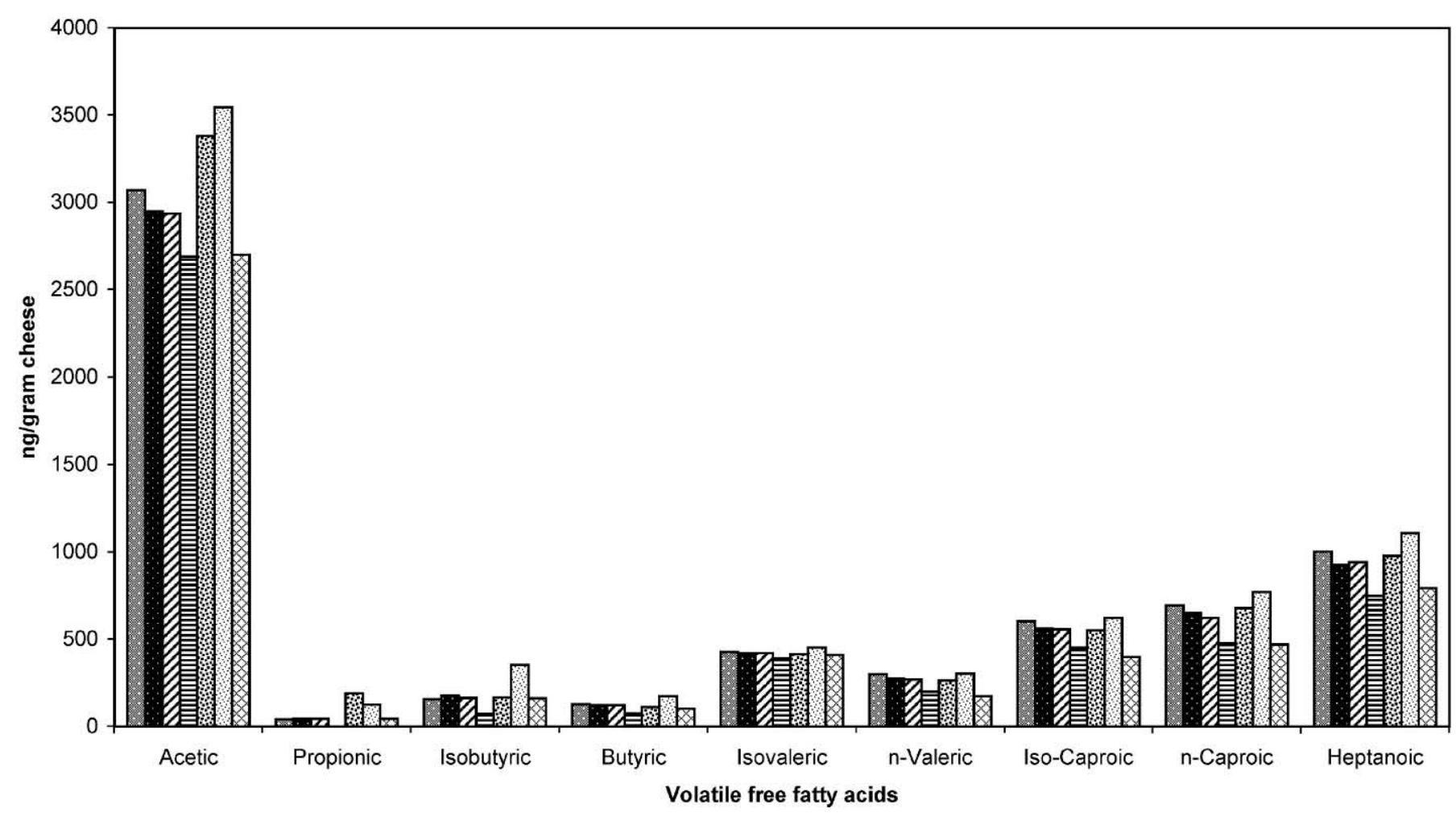

Figure 4. Volatile free fatty acids profile of 3-mo Edam cheeses : full-fat control cheese (FF), reduced-fat control cheese (RF), reducedfat cheese with Brevibacterium linens (BL), reduced-fat cheese with Lactococcus lactis ssp. diacetylactis (DC), reduced-fat cheese with Lactobacillus helveticus (HV), reduced-fat cheese with Lactobacillus reuteri (RT), reduced-fat cheese with mixed adjunct cultures (MX). Relative concentration (ng/g cheese) expressed based on cheese weight and internal standard recovery.

cheeses had the lowest amounts of this acid at the same ripening time.

Production of acetic and propionic acids in addition to lactic acid contribute to the overall acidity of Cheddar cheese (Banks et al., 1995). Propionate was found to be produced from amino acids in casein; casein had been reported to be a significant source of volatile free fatty acid (acetic acid to caproic acid) (Nakae and Elliot, 1965; Dulley and Greive, 1974). The results from this study showed that levels of propionic acid in most cheeses increased with ripening $(P<0.01)$ (Table 2$)$, except for cheese with $L$. helveticus, which decreased $(P<0.01)$. The full-fat control cheese had the highest level of this acid during 3 - and 6 -mo ripening $(P<$ 0.01 ). The level of propionic acid has been reported to be a good predictor of Cheddar cheese age (Marsili, 1985).

Butyric and iso-butyric acid levels in most cheeses increased with ripening (Table 2). Butyric acid is the most important low molecular weight fatty acid formed by lipases from milk, starter, and nonstarter bacteria (Bhowmik and Marth, 1990). Full-fat control cheese had a larger amount of butyric acid than did the reduced-fat cheeses at 6 -mo ripening $(P<0.01)$ (Table 2 ). This finding agreed with results reported by Chin and Rosenburg (1997) and Johnson and Chen (1995). Lipases have little or no effect on soluble esters (Law, 1997). Thus, lipases are distinguished by the physical state of the substrate rather than by the type of bond hydrolyzed. In addition, full-fat cheese has a greater area of lipid-water interface than does the reduced fat cheeses, which makes full-fat cheese more prone to lipolysis than reduced-fat cheese.

Iso-valeric acid levels increased with ripening in most cheeses $(P<0.01)$ (Table 3$)$. Iso-valeric acid was proposed as the deamination product of valine because milk fat does not contain glycerides with iso-valeric acid moiety (Lamparsky and Klimes, 1981). Valine is one of the principal amino acids derived from proteolytic activity of starter and nonstarter bacteria $(\mathrm{Pu}-$ chades et al., 1989). Reduced-fat cheese containing $L$. helveticus had higher proteolytic activity based on the total free amino acids than did other cheeses (Tungjaroenchai et al., 2001); however, this did not correspond 


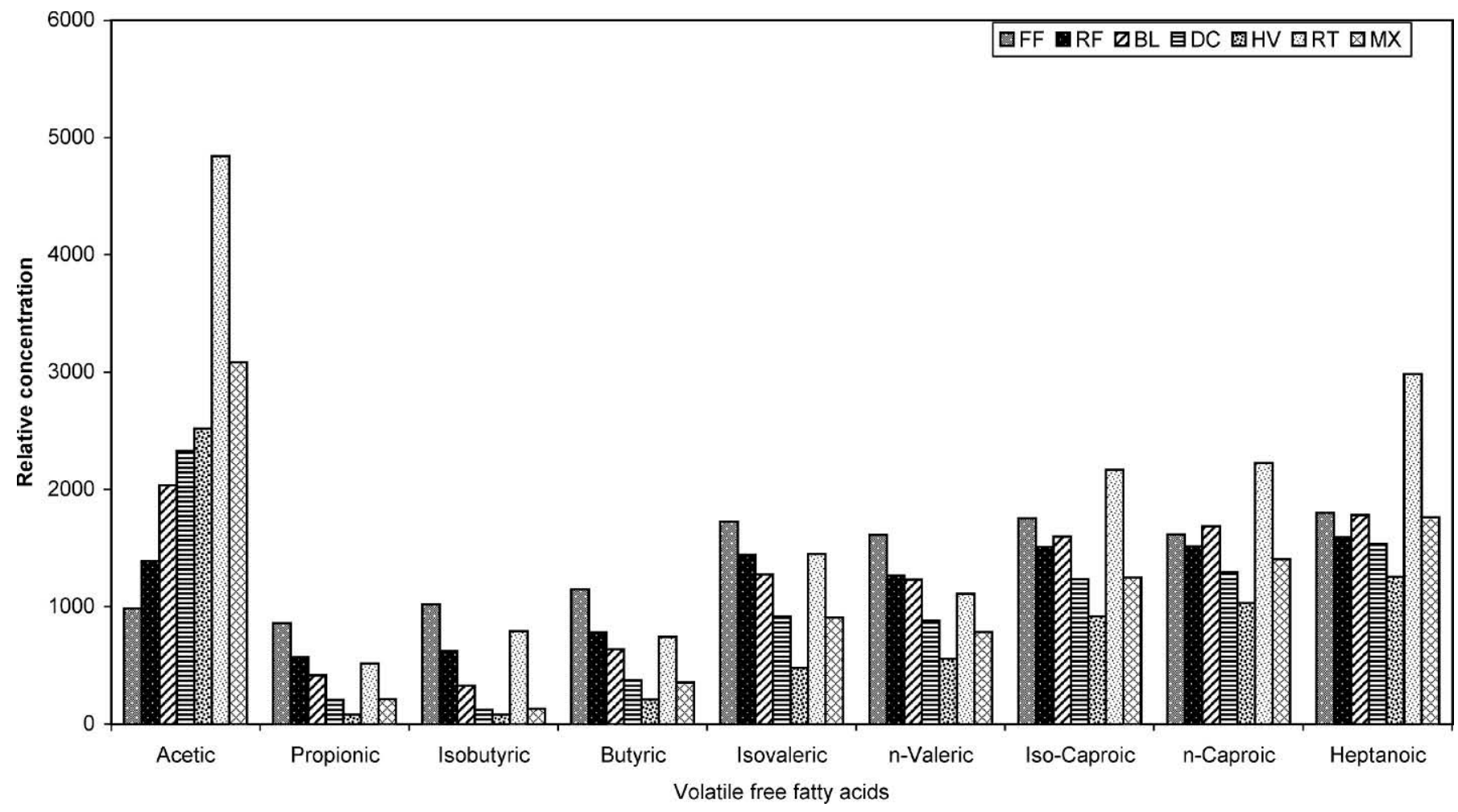

Figure 5. Volatile free fatty acids profile of 6-mo Edam cheeses : full-fat control cheese (FF), reduced-fat control cheese (RF), reducedfat cheese with Brevibacterium linens (BL), reduced-fat cheese with Lactococcus lactis ssp. diacetylactis (DC), reduced-fat cheese with Lactobacillus helveticus (HV), reduced-fat cheese with Lactobacillus reuteri (RT), reduced-fat cheese with mixed adjunct cultures (MX). Relative concentration (ng/g cheese) expressed based on cheese weight and internal standard recovery.

to the level of iso-valeric acid in cheese in this study. In contrast, cheeses with $L$. helveticus contained the lowest relative concentration of this acid (Table2) at 6 -mo ripening. Concentrations of iso-valeric acid in full-fat, reduced-fat, and reduced-fat cheeses with $L$.

Table 5. Relative concentration (ppm) of total volatile free fatty acids in headspace of Edam cheese.

\begin{tabular}{llll}
\hline $\begin{array}{l}\text { Cheese } \\
\text { treatments }\end{array}$ & & & \\
\hline $\mathrm{FF}$ & $1 \mathrm{mo}$ & $3 \mathrm{mo}$ & $6 \mathrm{mo}$ \\
$\mathrm{RF}$ & $6.41^{\mathrm{b}}$ & $2.98^{\mathrm{cB}}$ & $12.54^{\mathrm{aB}}$ \\
$\mathrm{BL}$ & $6.12^{\mathrm{b}}$ & $1.99^{\mathrm{cC}}$ & $10.71^{\mathrm{aBC}}$ \\
$\mathrm{DC}$ & $6.07^{\mathrm{b}}$ & $1.38^{\mathrm{cC}}$ & $11.00^{\mathrm{aBC}}$ \\
$\mathrm{HV}$ & $5.15^{\mathrm{b}}$ & $6.06^{\mathrm{bA}}$ & $8.90^{\mathrm{aCD}}$ \\
$\mathrm{RT}$ & $4.97^{\mathrm{a}}$ & $5.45^{\mathrm{aA}}$ & $7.14^{\mathrm{aD}}$ \\
$\mathrm{MX}$ & $7.45^{\mathrm{b}}$ & $5.73^{\mathrm{bA}}$ & $16.84^{\mathrm{aA}}$ \\
\hline
\end{tabular}

a,b,c Means without a common letter within a row $(P<0.01)$.

A,B,C Means without a common letter within a column $(P<0.01)$.

${ }^{1}$ Full-fat control cheese (FF), reduced-fat control cheese (RF), reduced-fat cheese with Brevibacterium linens (BL), reduced-fat cheese with Lactococcus lactis ssp. diacetylactis (DC), reduced-fat cheese with Lactobacillus helveticus (HV), reduced-fat cheese with Lactobacillus reuteri (RT), reduced-fat cheese with mixed adjunct cultures (MX). reuteri were similar at 6 -mo ripening. It is proposed that more than one pathway in addition to deamination is involved in iso-valeric acid production.

Changes in levels of free fatty acids were clearly detected in 3 - and 6 -mo cheeses $(P<0.01)$ (Figures 4 and 5). Certain adjunct cultures showed a definite role in lipolysis at particular times during cheese ripening. The 3-mo cheese with L. lactis ssp. diacetylactis, which had the highest lipase activity in pure culture, produced the highest levels of butyric, iso-valeric, n-valeric, iso-caproic, and n-caproic acid (Table 4$)(P<$ 0.01 ). In contrast, the highest levels of medium-chain fatty acids such as iso-caproic, n-caproic, and heptanoic acid (Table 4 ) in cheese with $L$. reuteri were detected in 6 -mo aged cheese $(P<0.01)$, although $L$. reuteri displayed the lowest lipase activity in pure culture. This suggested that the role of adjunct cultures in lipolysis is ripening time related. After 6-mo ripening, reduced-fat cheese with Lactobacillus reuteri had the highest relative concentration of total volatile free fatty acids $(P<0.01)$ (Table 5$)$, and reduced-fat cheese with $L$. helveticus had the lowest relative total concentration of these acids. Lactobacillus reuteri displayed weak lipolytic activity in broth cultures, results sug- 
Table 6. Flavor intensities of the sensory attributes of cheeses at 3 and 6 mo ripening.

\begin{tabular}{lll}
\hline Attribute & $3 \mathrm{mo}$ & $6 \mathrm{mo}$ \\
\hline Cooked & $3.66^{\mathrm{a}}$ & $3.55^{\mathrm{a}}$ \\
Whey & $3.52^{\mathrm{a}}$ & $3.27^{\mathrm{b}}$ \\
Diacetyl & $0.98^{\mathrm{a}}$ & $0.77^{\mathrm{b}}$ \\
Fresh milkfat/lactone & $2.59^{\mathrm{a}}$ & $2.25^{\mathrm{b}}$ \\
Fruity & $0.14^{\mathrm{b}}$ & $0.24^{\mathrm{a}}$ \\
Sulfur & $0.66^{\mathrm{b}}$ & $1.17^{\mathrm{a}}$ \\
Free fatty acid/rancid & $0.07^{\mathrm{b}}$ & $0.16^{\mathrm{a}}$ \\
Brothy & $1.88^{\mathrm{b}}$ & $2.34^{\mathrm{a}}$ \\
Nutty & $0.13^{\mathrm{b}}$ & $0.29^{\mathrm{a}}$ \\
Salty & $2.41^{\mathrm{a}}$ & $2.32^{\mathrm{a}}$ \\
Sweet & $1.17^{\mathrm{b}}$ & $1.33^{\mathrm{a}}$ \\
Bitter & $0.72^{\mathrm{b}}$ & $1.15^{\mathrm{a}}$ \\
Sour & $3.08^{\mathrm{a}}$ & $3.24^{\mathrm{a}}$ \\
Umami/savory & $0.27^{\mathrm{b}}$ & $0.62^{\mathrm{a}}$ \\
\hline
\end{tabular}

a,b,c Means within a row with different letters are significantly different $(P<0.05)$.

gested that more extensive lipolytic activity was possible if high numbers of this adjunct culture were present in cheese for a long period of time. In addition, the autolytic properties of microbial cells might be considered. These properties were found to be strain dependent (El-Soda et al., 2000).

\section{Sensory Evaluation}

Free fatty acid and basic tastes such as sour were perceived as more pronounced in 6- than in 3-mo cheeses $(P<0.05)$. However, descriptive panelists did not detect differences among cheese treatments after 3 and 6 mo ripening, although differences in specific flavors occurred with aging for all cheeses (Table 6). All cheese treatments were similar among the evaluated attributes, as indicated by the descriptive panelists. Similarly, Weimer et al. (1997) found that lipase activity of adjunct cultures ( $L$. helveticus and $B$. linens) in reduced-fat cheeses was not correlated to an increase in flavor in Cheddar type cheese.

\section{CONCLUSIONS}

Adjunct cultures influenced volatile free fatty acids production in reduced-fat Edam cheese. Differences in volatile free fatty acid production did not produce detectable sensory differences among the treatments after 3 or 6 mo of aging. Reduced-fat cheese with $L$. reuteri had the highest relative concentration of total volatile free fatty acids in 6 -mo cheese. Volatile free fatty acids did not play much of a role in young cheeses; however, either individually or in the combination of adjunct cultures, fat, and ripening time could independently influence the production of these free fatty acids.

\section{REFERENCES}

Aston, J. W., and J. R. Dulley. 1982. Cheddar cheese flavor. Aust. J. Dairy Technol. 47:59.

Association of Official Analytical Chemists. 1995. Official Methods of Analysis. Vol. II. 16th ed. AOAC, Arlington, VA.

Bardi, L., V. Dell'Oro, and C. Delfini.1992. Esterase activity in wine yeast. Rtv. Vinic. Enol.45:17-27.

Banks, J. M., E. Y. Brechany, W. W. Christie, E. A. Hunter, and D. D. Muir. 1995. Cheddar cheese flavor and chemical indices: Changes during maturation. Pages 99-112 in Chemistry of Structure-Function Relationships in Cheese. E. L. Malin and M. H. Tunick, eds. Plenum Press, New York, NY.

Blake, M. R., R. Koka, and B. C. Weimar. 1996. A semiautomated reflectance colorimetric method for the determination of lipase activity in milk. J. Dairy Sci. 79:1164-1171.

Bhowmik, T., and E. H. Marth. 1990. A review. Role of micrococcus and pediococcus species in cheese ripening. J. Dairy Sci. 73:859-866.

Boutrou, R., A. Sepulcher, J. C. Gripon, and V. Monnet.1998. Simple tests for predicting the lytic behavior and proteolytic activity of lactococcal strains in cheese. J. Dairy Sci. 81:2321-2328.

Bradley, R. L., Jr., E. Arnold, Jr., D. M. Barbano, R. G. Semerad, D. E. Smith, and B. K. Vines. 1992. Chemical and physical methods. Pages 490-492 in Standard Methods for Examination of Dairy Products. R. T. Marshall, ed. 16th ed. American Public Health Association, Washington, DC.

Chavarri, F., M. Virto, C. Martin, A. Najera, A. Santisteban, L. J. R. Barron, and M. De Renobales. 1997. Determination of free fatty acids in cheese: Comparison of two analytical methods. J. Dairy Res.64:445-452.

Chin, H. W., and M. Rosenberg. 1997. Accumulation of some flavor compounds in full and reduced-fat Cheddar cheese under different ripening conditions. J. Food Sci. 62:468-474.

Dias, B., and B. Weimer. 1995. A semi-automated colorimetric method for determination of aminopeptidase activity in turbid solutions. J. Rapid Methods Automation Microbiol. 3:223-235.

Dimos, A., G. E. Urbach, and A. J. Miller. 1996. Changes in flavor and volatiles of full-fat and reduced-fat Cheddar cheese during maturation. Int. Dairy J. 6:981-995.

Drake, M. A., S. C. McIngvale, K. R. Cadwallader, and G. V. Civille. 2001. Development of a descriptive sensory language for Cheddar cheese. J. Food Sci. 66:1422-1427.

Dulley, J. R., and P. A. Grieve. 1974. Volatile fatty acid production in Cheddar cheese. Aust. J. Dairy Technol.29:120-123.

El-Soda, M., M. Korayem, and N. Ezzat. 1986. The esterolytic and lipolytic activities of lactobacilli. III. Detection and characterization of the lipase system. Milchwissenschaft 41:353-355.

El-Soda, M., A. A. Hantira, N. Ezzat, and H. K. El-Shafei. 1992. Accelerated ripening of Ras cheese using freeze-shocked mutant strains of $L b$. casei. Food Chem. 44:179-184.

El-Soda, M., J. Law, E. Tsakalidou, and G. Kalantzopoulous. 1995. Pages 1023-1184 in Food Flavors: Generation, Analysis, and Process Influence. Proceedings of the 18th. International flavor conference, Cos, Greece. G. Charalambous, ed. Elsevier Sci., Amsterdam, The Netherlands.

El-Soda, M., S. A. Madkor, and P. S. Tong. 1999. Evaluation of commercial adjuncts for use in cheese ripening: 1. Enzymatic activities and autolytic properties of freeze-shocked adjuncts in buffer system. Milchwissenschaft 54:85-89.

El-Soda, M., S. A Madkor, and P. S. Tong. 2000. Adjunct cultures: Recent developments and potential significance to the cheese industry. J. Dairy Sci. 83:609-619.

Fox, P. F., T. K. Singh, and P. L. H. McSweeney. 1995. Biogenesis of flavor compounds in cheese. Pages 59-98 in Chemistry of Structure-Function Relationships in Cheese. E. L. Malin and M. H. Tunick, eds. Plenum Press, New York, NY.

Fox, P. F., T. P. Guinee, T. M. Cogan, and P. L. H. McSweeney. 2000. Fundamentals of Cheese Science. Aspen Publishers, Inc., Frederick, MD. 
Gobbetti, M., P. F. Fox, and L. Stepaniak.1996. Estereolytic and lipolytic activities of mesophilic and thermophilic lactobacilli. Ital. J. Food Sci. 8:127-135.

Gripon, J-C. 1987. Mould-ripened cheeses. Page 400 in Cheese: Chemistry, Physics and Microbiology. Volume 2. P. F. Fox, ed. Elsevier Science Publishers, London, UK.

Gripon, J-C. 1993. Moulded-ripened cheeses. Page 543 in Cheese: Chemistry, Physics and Microbiology. 2nd ed. volume 2. P. F. Fox, ed. Chapman \& Hall, London, UK.

Innocente, N., S. Moret, C. Corradini, and L. S. Conte. 2000. A rapid method for the quantitative determination of short-chain free volatile fatty acids from cheese. J. Agric. Food Chem.48:33213323.

Jeon, I. J. 1994. Chemistry of dairy lipids. Review of free fatty acids. ACS Symp. Ser. 558:196-207.

Johnson, M. E., and C. M. Chen. 1995. Technology of manufacturing reduced-fat Cheddar cheese. Pages 331-338 in Chemistry of Structure-Function Relationships in Cheese. E L. Malin and M. H. Tunick, eds.. Plenum Press, New York, NY.

Law, B. A. 1985. Advances in Microbiology and Biochemistry of Cheese and Fermented Milk. F. L. Davies, F. L. and B. Law, eds. Elsevier Applied Science, London, UK.

Law, B. A.1997. Microbiology and Biochemistry of Cheese and Fermented Milk. Blackie Chapman \& Hall, London, UK.

Lawrence, R. C., J. Gilles, and L. K. Creamer. 1993. Cheddar cheese and related dry-salted cheese varieties. Page 577 in Cheese: Chemistry, Physics, and Microbiology. Volume 2. 2nd ed. P. F. Fox, ed. Chapman \& Hall. London, UK.

Lamparsky, D., and I. Klimes. 1981. Cheddar cheese flavor. Its formation in the light of new analytical results. Page 557 in Flavor '81. A. Schreier, ed. Third Weurman Symposium. Proceedings of the International Conference. Walter de Gruyter \& Co., Berlin, Germany.

Lee, S. Y., and B. H. Lee. 1989. Production and characterization of esterase-lipase of Lactobacillus casei ssp. pseudoplantarum LE2. Biotechnol. Appl. Biochem. 11:552-563.

Madkor, S. A., M. El Soda, and P. S. Tong. 1999. Evaluation of commercial adjuncts for use in cheese ripening: 2. Ripening aspects and flavor development in cheese and curd slurries prepared with adjunct lactobacilli. Milchwissenschaft 54:133-137.
Madkor, S. A., P. S. Tong, and M. El Soda. 2000. Ripening of Cheddar cheese with added attenuated adjunct cultures of lactobacilli. J. Dairy Sci. 83:1684-1691.

Marsili, R. 1985. Monitoring chemical changes in cheddar during aging by HPLC and GC techniques. J. Dairy Sci. 68:3155-3161.

Meilgaard, M., G. V. Civille, and B. T. Carr. 1991. Sensory Evaluation Techniques. 2nd ed. CRC Press, Boca Raton, FL.

Nakae, T., and J. A. Elliot. 1965. Volatile fatty acids produced by some lactic acid bacteria. I. Factors influencing production of volatile fatty acids from casein hydrolyzates. J. Dairy Sci. 48:287-292.

Poveda, J. M., M. S. Pezez-Coello, and L. Cabezas. 1999. Evolution of the free fatty acid fraction in Manchego cheese during ripening. Milchwissenschaft 54:685-689.

Puchades, R., L. Lemieux, and R. E. Simard.1989. Evolution of free amino acids during the ripening of Cheddar cheese containing added lactobacilli strains. J. Food Sci. 54:885-888, 946.

Smith, P. K., R. I. Krohn, G. T. Hermanson, A. K. Mallia, F. H. Gartner, M. D. Provenzano, E. K. Fujimoto, N. M. Goeke, B. J. Olson, and D. C. Klenk. 1985. Measurement of protein using bicinchoninic acid. Anal. Biochem. 150:76-85.

Suriyaphan, O., M. A. Drake, X. Q. Chen, and K. R. Cadwallader. 2001. Characteristic aroma components of British farmhouse Cheddar cheese. J. Agric. Food Chem. 49:1382-1387.

Thomas, T. D. 1987. Acetate production from lactate and citrate by non-starter bacteria in Cheddar cheese. N.Z. J. Dairy Sci. Technol. 22:25-38.

Tungjaroenchai, W., M. A. Drake, and C. H. White. 2001. Influence of adjunct cultures on ripening of reduced fat Edam cheeses. J. Dairy Sci. 84:2117-2124.

Urbach, G. 1997. The flavour of milk and dairy products: II. Cheese: contribution of volatile compounds. Int. J. Food Technol. 50:79-89.

Weimer, B., B. Dias, M. Ummadi, J. Broadbent, C. Brennand, J. Jaegi, M. Johnson, F. Milani, J. Steele, and D. V. Sisson.1997. Influence of $\mathrm{NaCl}$ and $\mathrm{pH}$ on intracellular enzymes that influence Cheddar cheese ripening. Lait 77:383-398.

White, C. H., J. R. Bishop, and D. M. Morgan. 1992. Microbiological methods for dairy products. Pages 277-303 in Standard Methods for Examination of Dairy Products. R. T. Marshall, ed. 16th ed. American Public Health Association, Washington DC. 